\title{
A retrospective search for bovine respiratory syncytial virus (BRSV) antigens in histological specimens by immunofluorescence and immunohistochemistry ${ }^{1}$
}

\author{
Eduardo F. Flores²*, Rudi Weiblen², Margareti Medeiros ${ }^{3}$, Sônia A. Botton², Luiz F. \\ Irigoyen ${ }^{4}$, David Driemeier ${ }^{5}$, Luis F. Schuch ${ }^{6}$ e Mauro Moraes ${ }^{7}$
}

\begin{abstract}
Flores E.F., Weiblen R., Botton S.A., Medeiros M., Irigoyen L.F., Driemeier D., Schuch L.F. \& Moraes M.S. 2000. A retrospective search for bovine respiratory syncytial virus (BRSV) antigens in histological specimens by immunofluorescence and immunohistochemistry. Pesquisa Veterinária Brasileira 20(4):139-143. Depto Medicina Veterinária Preventiva, Universidade Federal de Santa Maria, 97105-900 Santa Maria, RS, Brazil.

Bovine respiratory syncytial virus (BRSV) has been only sporadically identified as a causative agent of respiratory disease in Brazil. This contrasts with frequent reports of clinical and histopathological findings suggestive of BRSV-associated disease. In order to examine a possible involvement of BRSV in cases of calf pneumonia, a retrospective search was performed for BRSV antigens in histological specimens submitted to veterinary diagnostic services from the states of Rio Grande do Sul and Minas Gerais. Ten out of 41 cases examined $(24.4 \%$ were positive for BRSV antigens by immunohistochemistry (IPX). Eight of these cases $(19.5 \%$ were also positive by indirect immunofluorescence (IFA), and 31 cases $(75.6 \%$ were negative in both assays. In the lungs, BRSV antigens were predominantly observed in epithelial cells of bronchioles and less frequently found in alveoli. In one case, antigens were detected only in the epithelium of the alveolar septae. The presence of antigen-positive cells was largely restricted to epithelial cells of these airways. In two cases, positive staining was also observed in cells and cellular debris in the exudate within the pulmonary airways. The clinical cases positive for BRSV antigens were observed mainly in young animals (2 to 12 month-old) from dairy herds. The main microscopic changes included bronchointerstitial pneumonia characterized by thickening of alveolar septae adjacent to airways by mononuclear cell infiltrates, and the presence of alveolar syncytial giant cells. In summary, the results demonstrate the suitability of the immunodetection of viral antigens in routinely fixed tissue specimens as a diagnostic tool for BRSV infection. Moreover, the findings provide further evidence of the importance of BRSV as a respiratory pathogen of young cattle in southeastern and southern Brazil.
\end{abstract}

INDEX TERMS: Bovine respiratory syncytial virus, BRSV, immunohistochemistry, immunofluorescence, diagnosis.

${ }^{1}$ Accepted for publication on May 29, 2000.

This study was supported by MCT, CNPq, CAPES and Finep (PRONEX em Virologia Veterinária, 215-96).

${ }^{2}$ Departamento de Medicina Veterinária Preventiva e Depto Microbiologia e Parasitologia, Universidade Federal de Santa Maria (UFSM), Santa Maria, RS, 97105-900 Brazil.

${ }^{3}$ Mestranda em Medicina Veterinária, UFSM.

${ }^{4}$ Departamento de Patologia, UFSM.
${ }^{5}$ Faculdade de Veterinária, Universidade Federal do Rio Grande do Sul (UFRGS), Porto Alegre, RS.

${ }^{6}$ Faculdade de Veterinária, Universidade Federal de Pelotas (UFPEL), Pelotas, RS.

${ }^{7}$ Departamento de Medicina Veterinária, Universidade Federal de Viçosa (UFV), Viçosa, MG.

*Corresponding author: DMVP, CCR, UFSM 97105-900 Santa Maria, RS, Brazil. Fax: (055) 220-8055. E-mail: Flores@ ccr.ufsm.br 
RESUMO.- [Pesquisa retrospectiva de antígenos do Vírus Respiratório Sincicial Bovino (BRSV) em cortes histológicos por imunofluorescência e imunohistoquímica.] 0 Vírus Respiratório Sincicial Bovino (BRSV) tem sido raramente identificado como agente etiológico de doença respiratória em bovinos no Brasil. Isso contrasta com freqüentes relatos clínicos e histopatológicos sugestivos de enfermidade associada ao BRSV. Com o objetivo de investigar o possível envolvimento do BRSV em casos de pneumonia em bovinos jovens, realizou-se uma pesquisa retrospectiva para antígenos do BRSV em cortes histológicos de materiais submetidos a quatro serviços de diagnóstico nos Estados do Rio Grande do Sul e Minas Gerais. Dez entre 41 casos examinados $(24,4 \%)$ foram positivos para antígenos do BRSV por imunohistoquímica (IPX). Oito desses casos (19,5\% também foram positivos por imunofluorescência (IFA) e 31 casos $(75,6 \%$ foram negativos em ambos os testes. Nos pulmões, antígenos virais foram detectados predominantemente nas células epiteliais dos bronquíolos e menos freqüentemente nos alveólos. Em um caso, antígenos virais foram detectados exclusivamente no epitélio alveolar. A presença de células positivas restringiu-se ao epitélio dessas vias aéreas. Em dois casos, antígenos virais foram detectados em células descamativas e em restos celulares no exsudato das vias aéreas. Os casos positivos para antígenos do BRSV eram oriundos principalmente de animais jovens (2 a 12 meses de idade) de rebanhos leiteiros. As principais alterações histológicas observadas foram pneumonia bronco-intersticial caracterizada por espessamento dos septos alveolares adjacentes às vias aéreas, infiltrados de células mononucleares e presença de células gigantes multinucleadas nos alveólos. Os resultados obtidos demonstram a utilidade dos métodos de detecção de antígenos em cortes histológicos para o diagnóstico da infecção pelo BRSV. Além disso, esses resultados confirmam evidências anteriores sobre a importância do BRSV como patógeno respiratório no sudeste e sul do Brasil.

TERMOS DE INDEXAÇÃO: Vírus respiratório sincicial bovino, BRSV, imunohistoquímica, imunofluorescência, diagnóstico.

\section{INTRODUCTION}

Bovine respiratory syncytial virus (BRSV) has been associated with respiratory disease in calves worldwide, and evidence is accumulating that BRSV is an economically important pathogen of cattle (Baker 1986). BRSV has been frequently detected in epizootics of respiratory tract disease in young cattle characterized by severe clinical and pathological changes (Bryson et al. 1979, Van der Hingh 1982, Bryson et al. 1983, Elvander 1996, Driemeier et al. 1997). Clinical disease in adult cattle has also been occasionally reported (Elvander 1996, Driemeier et al. 1997). Diagnosis of BRSV infection has been usually accomplished by virus isolation, immunodetection of viral antigens in secretions and tissues and/or demonstration of seroconversion (Wellemans 1977, Thomas \& Stott 1981, McNulty et al. 1983, Baker 1986). Serological data, as well as clinical and virological findings, indicate that BRSV infection is widespread among cattle (Baker 1986).
Very little is known about BRSV infections and associated diseases in Brazil. The virus was first identified in lung tissues of calves collected in a slaughterhouse (Gonçalves et al. 1993) and subsequently isolated from calves with respiratory disease (Campalans \& Arns 1995). Recently, the virus was isolated and seroconversion to BRSV was demonstrated in an outbreak of respiratory disease affecting both young and adult cattle (Driemeier et al. 1997). In spite of the few reports of virus identification, field cases with clinical and pathological manifestations suggestive of BRSV infection are not rare in Brazilian veterinary diagnostic services. Recent serological data also demonstrate the presence of BRSV infection among Brazilian cattle (Campalans \& Arns 1997). Nevertheless, the inability to isolate the virus and/or to demonstrate virus antigens in clinical specimens has left most of these cases undiagnosed (or misdiagnosed). In addition to the small number of laboratories conducting virological diagnosis, reagents for BRSV identification in clinical specimens are not generally available. This is partly due to the lack of information about the occurrence and distribution of BRSV infection among Brazilian cattle.

In order to examine a possible involvement of BRSV in cases of calf pneumonia, we performed a retrospective search for BRSV antigens in histological specimens submitted to four veterinary diagnostic laboratories from southeastern and southern Brazil.

\section{MATERIAL AND METHODS}

Clinical cases of respiratory disease in young cattle, including some with clinical and histopathological findings very suggestive of BRSVassociated disease, were selected and lung sections were initially examined by indirect immunofluorescence (IFA). Subsequently, the sections were submitted to peroxidase-based immunohistochemistry (IPX). The clinical history and histological findings of the clinical cases of origin of the tissue samples examined are listed in Table 1. Serial $5 \mathrm{~mm}$ sections from each block of formalin-fixed, paraffinembedded tissues were mounted in organosilane (Sigma Inc., St.Louis, MO) treated slides and allowed to dry overnight at $60^{\circ} \mathrm{C}$. Sections were deparaffinized, rehydrated and treated with trypsin $(0.00125 \mathrm{mg}$ in $50 \mathrm{ml}$ of $0.01 \mathrm{M}$ PBS, pH 7.2) for $10 \mathrm{~min}$ at room temperature. For IFA, slides were blocked with $5 \%$ horse serum for $30 \mathrm{~min}$ at room temperature. After blocking, the sections were incubated with the monoclonal antibody (MAb) 15c7 (ascitic fluid 1:100 in PBS) for one hour at $37^{\circ} \mathrm{C}$, followed by three washes in PBS (5 min each). Sections incubated with an irrelevant $M A b$ and lung sections of a calf which died of an unrelated cause were included in each test as controls for staining specificity. The slides were incubated with a FITC-conjugate goat anti-mouse IgG antibody (1:200 in PBS; Sigma) for an additional hour, washed in PBS and distilled water, counterstained with Evans Blue $(0.1 \% 1 \mathrm{~min})$, mounted with glycerol:PBS (1:1) and observed in an epifluorescence microscope.

For immunohistochemistry, after trypsin treatment the slides were submitted to four baths ( $5 \mathrm{~min}$ each) of $3 \% \mathrm{H}_{2} \mathrm{O}_{2}$ to inactivate endogenous peroxidase activity. Slides were then submitted to three block steps (15 each) as follows: $10 \%$ white egg in PBS; $5 \%$ non-fat milk; and $5 \%$ equine serum. After incubation with the primary antibody (Mab 15c7), a commercially available avidin-biotin complexperoxidase kit ( $A B C$ kit, Vector Laboratories, Burlingame, $C A$ ) was used according to the manufacturer's instructions. After addition 
of the substrate 3-3-diaminobenzidine (DAB, Sigma), the sections were stained with hematoxylin, dehydrated through successive ethanol and xylene baths and mounted for light microscopy. The specificity of BRSV-positive signal was subsequently confirmed by submitting all positive sections to IPX using a goat anti-BRSV antiserum (VMRD Inc., Pullman, WA) followed by a biotin-streptavidin based detection system (Dako Co., Carpinteria, CA).

\section{RESULTS AND DISCUSSION}

Eight out of 41 cases examined (19.5\% were positive for BRSV antigens by IFA. The IFA-positive tissues and two additional cases were also positive by IPX, resulting in a total of 10 BRSV antigen-positive cases (24.4\% Table 1). The localization of antigens exclusively in the cytoplasm of bronchiolar and alveolar epithelial cells facilitated the diagnosis (Fig. 1 and 2). No staining was observed in the lung sections used as negative control, either by IFA or IPX.

The IFA assay has been used for detection of BRSV antigens in nasopharyngeal material and lung sections of naturally and experimentally inoculated animals (Wellemans 1977, Thomas \& Stott 1981, McNulty et al. 1983, Baker 1986). This technique has shown some advantages over virus isolation, including speed and simplicity, but particularly the higher sensitivity and the possibility of detection of antigens of nonviable virus even up to $48 \mathrm{~h}$ after death (Tomas \& Stott 1981, Van der Hingh 1982, Baker 1986). Among the cases examined in this study, virus isolation had been attempted in three occasions, only one being positive for virus. In the remaining

Table 1. Detection of BRSV antigens in histological sections from clinical specimens submitted to four veterinary diagnostic services from southeastern and southern Brazil (1984-1998)

\begin{tabular}{ccccc}
\hline $\begin{array}{c}\text { Case } \\
\text { no. }\end{array}$ & $\begin{array}{c}\text { Date } \\
\text { (local) }\end{array}$ & Clinical, histological and microbiological findings & IFA & IPX
\end{tabular}

1 1998-RS Six-month-old heifer, Jersey dairy herd. Cough, nasal secretion and respiratory distress followed by death. Other calf had died an eight calves had showed similar signs. Interstitial pneumonia with numerous multinucleated giant cells.

Virus isolation negative (BHV-1, BVDV, PI-3 and BRSV).

1998-RS Six-month-old heifer, Jersey dairy herd. Antero-ventral pneumonia with many syncytial cells; tissues fixed in Bouin's fluid for more than 2 years. BRSV suspected. Virus isolation not attempted.

3 1998-RS Two-month-old calves (2) from an affected dairy herd. Severe respiratory disease.Viral isolation not attempted.

4 1998-RS Calf with fibrinopurulent pneumonia, suggestive of Pasteurella sp, but with some syncytial cells. BRSV and PI-3 suspected. Virus isolation not attempted.

5 1997-RS Two-year-old cow, history of persistent respiratory disease. Histologically, non-specific granuloma, Ziehl-Neelsen positive. Viral isolation not attempted.

6 1996-RS Six-month-old Holstein calves. Antero-ventral pneumonia with many syncytial cells. BRSV suspected. Virus isolation not attempted.

7 1996-RS Two 4-year-old cows, beef cattle herd. Chronic cough and severe dyspnea; alveolar emphysema, peribronchiolar muscle hypertrophy, moderate inflammatory reaction with many multinucleated cells in the alveoli and bronchiolar epithelium. BRSV antigens demonstrated by IFA on cryostat sections; positive for virus isolation.

8 1994-RS Three-year-old cow, Jersey dairy herd. History of respiratory disease. Histologically, non-specific granuloma, Ziehl-Neelsen negative. Viral isolation not attempted.

9 1986-MG Male, one-year-old calf, Jersey dairy herd. Antero-ventral pneumonia moderate inflammatory reaction with a few multinucleated cells. BRSV and PI-3 suspected.Virus isolation not attempted.

10 1984-MG Female, 4-month-old Holstein calf. Fibrinopurulent pneumonia. Virus isolation not attempted.

\section{Bronchioles, terminal bronchioles $(+++)^{\mathrm{a}}$, exudate cells $(+)$}

exudate cells $(+)$

$\begin{array}{lll}+ & + & \text { Bronchioles }(+) \\ - & + & \text { Bronchioles }(++) \\ + & + & \begin{array}{l}\text { Alveolar epithelium }(+++) \\ \text { bronchioles }(+)\end{array} \\ + & & \begin{array}{l}\text { Bronchioles }(++) \\ +\end{array} \\ + & \begin{array}{l}\text { Bronchioles and terminal bronchioles }(+++) \\ \text { exudate cells }(+)\end{array} \\ & & \text { Bronchioles }(++)\end{array}$

$+\quad+\quad$ Bronchioles and terminal bronchioles $(++)$

$+\quad+\quad$ Bronquioles $(+)$, alveoli $(+)$

$+\quad+\quad$ Alveolar epithelium $(++)$

aFrequency and distribution of antigen-positive cells: (+) few positive cells, $(++)$ moderate number of positive cells and bronchioles affected, $(+++)$ extensive involvement of bronchioles. 


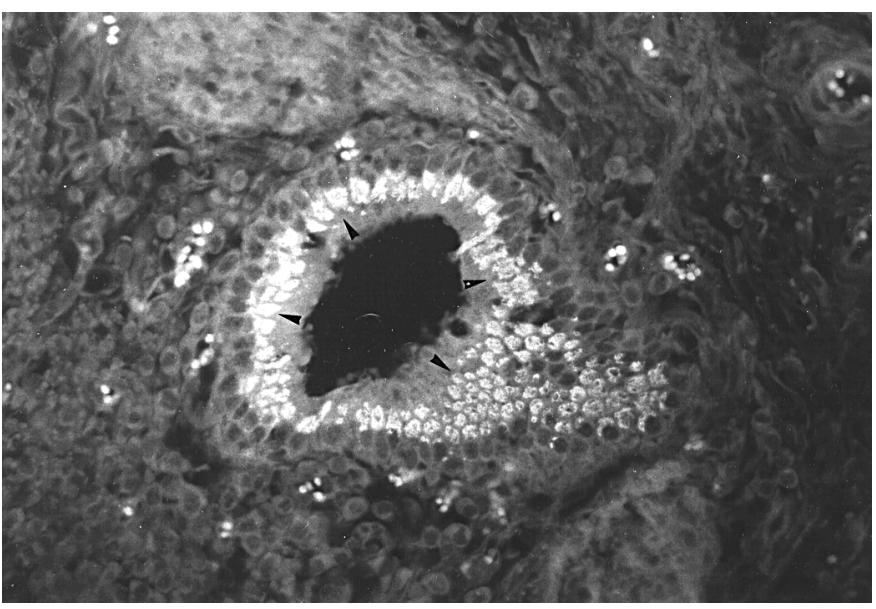

Fig. 1. Lung of calf diagnosed positive for BRSV antigens (case no. 1). Formalin-fixed, paraffin embedded lung section was submitted to indirect immunofluorescence using $\mathrm{MAb} 15 \mathrm{C} 7$ as primary antibody. Counterstained with Evans Blue. Note specific fluorescence in epithelial cells of a terminal bronchiole (arrow heads). Obj.16.

cases, either virus isolation was not attempted or not achieved.

In the present study, IFA showed advantages of speed, simplicity and absolute absence of non-specific staining over the IPX. Nonetheless, IPX demonstrated a higher sensitivity, being able to consistently detect viral antigens in tissue sections from two cases which were repeatedly negative by IFA (Table 1). The reasons for this discrepancy are unclear, yet probably reflect an increased sensitivity of IPX due to the use of an avidin-biotin system. In any case, it has been previously demonstrated that both methods have some advantages over virus isolation when field material suspected of BRSV is to be investigated (Baker 1986).

Eight tissue sections were positive and 29 were negative in both assays. Among the negative tissue sections, there was one from a clinical case in which the virus had been previously isolated (Driemeier et al. 1997). However, this section remained a long time ( $>2$ years) in formalin, which could explain the failure of the MAb to react with viral antigens. Negative results by immunodetection were also obtained by testing tissues from two cases the clinical and histological findings of which were compatible with BRSV etiology (not shown). Another possible viral etiology compatible with those findings, i.e. parainfluenza-3 virus (PI3-V) was not investigated.

Within the lungs, BRSV antigens were predominantly observed in epithelial cells of bronchioles and in two cases found in the alveolar epithelium. In one of the latter, extensive alveolar staining was the most prominent finding, with little involvement of bronchioles. Multinucleated giant cells positive for BRSV antigens within the pulmonary parenchyma were observed in many cases (Fig. 3). In the pulmonary airways, the presence of antigen-positive cells was mainly restricted to epithelial cells. In a few cases positive staining was also observed in cells and cellular debris in the exudate

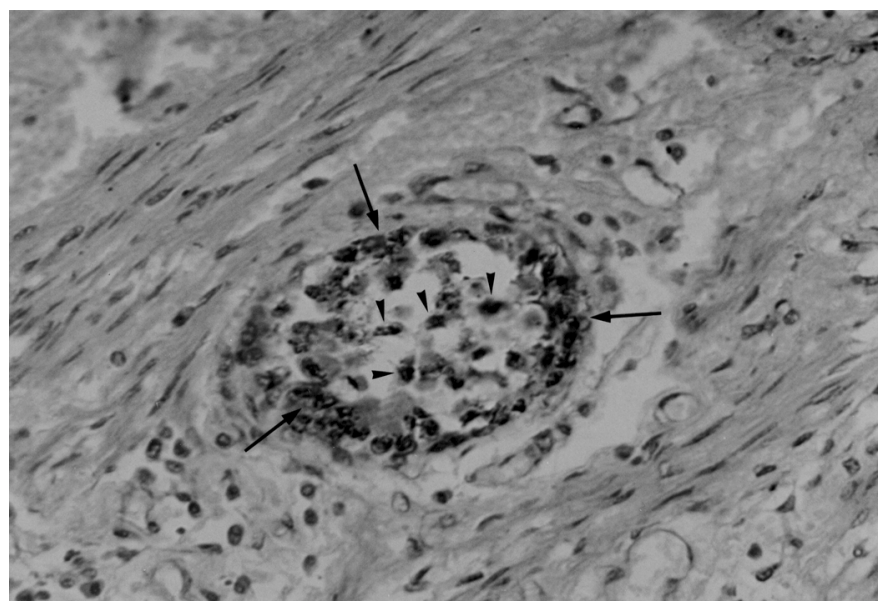

Fig. 2. Lung of calf diagnosed positive for BRSV antigens (case no. 4). Formalin-fixed, paraffin embedded lung section was submitted to immunohistochemistry using MAb $15 c 7$ as primary antibody and an avidin-biotin detection system. Specific signal is localized in the external epithelium (arrows) and in the septae of an alveolar sac (arrow heads). DAB chromogen and hematoxylin staining, obj. 16.

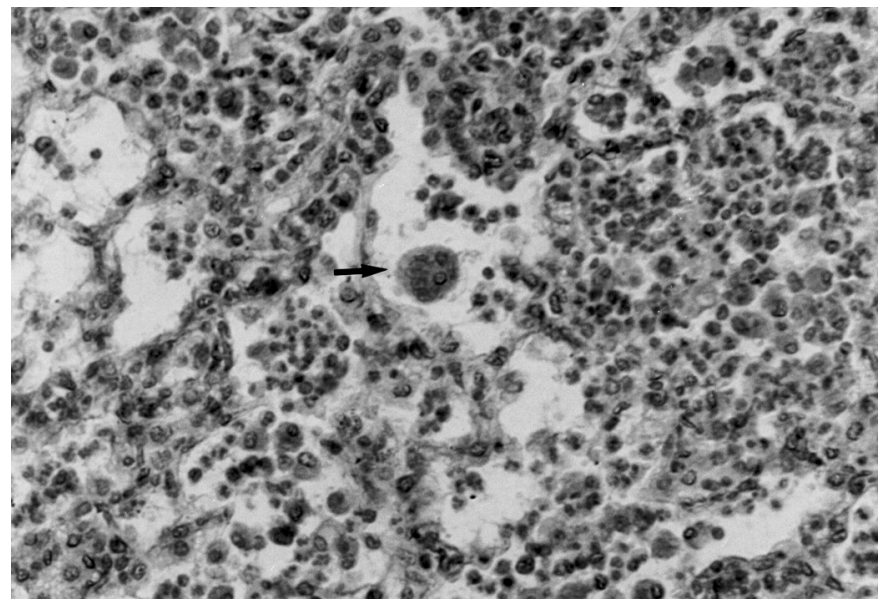

Fig. 3. Lung of calf diagnosed positive for BRSV antigens (case no. 1). Formalin-fixed, paraffin embedded lung section was submitted to immunohistochemical detection of viral antigens using a goat anti-BRSV policlonal antiserum and an streptavidin-biotin detection system. Note antigen-positive multinucleated cells in the pulmonary parenchyma (arrow). DAB chromogen and hematoxylin staining, obj. 16.

within the pulmonary ducts. In some sections, positive fluorescence was distributed as foci in only a few bronchioles, whereas in others there was an extensive involvement of bronchioles and terminal bronchioles (Table 1). In many cases, a more detailed study of the distribution of viral antigens was not possible due to the limited number of slides available. Likewise, tissue morphology was quite altered in some sections, probably reflecting inadequate fixation, processing or the consequence of long term storage.

The predominant bronchiolar localization of viral antigens detected here is in agreement with previous reports 
(Wellemans 1977) and contrasts with other studies reporting BRSV antigens predominantly in the alveoli (Thomas \& Stott 1981). Van den Hingh (1982) observed both patterns of antigen localization in calves naturally infected with BRSV. In the terminal bronchioles, viral antigens were observed in the cytoplasm of bronchiolar epithelial cells, whereas in the lung parenchyma fluorescence was detected along the alveolar septae, probably in the cytoplasm of alveolar epithelial cells (Van den Hingh 1982). Although both patterns of antigen distribution have been reported, histologically the bronchiolar epithelium seems to be the major target organ for BRSV (Van den Hingh 1982). In children, respiratory syncytial virus (RSV) causes two distinct patterns of disease: one characterized by bronchiolitis with no alveolar involvement and another with bronchiolitis accompanied by severe alveolar damage (Holzhauer \& Van Nieustadt 1976).

BRSV antigens were detected in tissues from two cases in which virus isolation and/or antigen detection had been previously carried out (Table 1). This was also the case in tissues where histopathological findings were suggestive of BRSV-associated disease, but virus identification was either not attempted or not achieved (Table 1, Fig. 3). Noteworthy were the positive cases identified among the many tissues originating from cases of calf pneumonia in which BRSV had not been suspected and/or investigated as the etiologic agent. These included cases of respiratory disease with poor clinical and/or histological information available (Table 1). Thus, cases of respiratory disease in young cattle, including those lacking clinical findings most commonly suggestive of BRSV associated disease, might be worthwhile to be investigated for a possible BRSV involvement.

In summary, our results demonstrate the suitability of the immunodetection of viral antigens in routinely fixed tissue specimens as a diagnostic tool for BRSV infection. The low viability of the virus under some environmental temperatures and the inadequate handling and conservation of clinical material are detrimental to virus isolation attempts (Baker 1986). These conditions may have contributed to frustrate some attempts to isolate the virus from field cases of respiratory disease by BRSV. In this sense, the availability of reagents and diagnostic methods for detection of viral antigens in clinical specimens will certainly improve the diagnosis of BRSV infection in Brazil. Moreover, our findings provide further evidence of the importance of BRSV as a respiratory pathogen of young cattle in southeastern and southern Brazil.

Acknowledgements:- The MAb 15c7 was kindly provided by Dr. Clayton Kelling (Department of Veterinary and Biomedical Sciences, University of Nebraska/Lincoln, Lincoln, NE). We thank Dr. Marlene Isabel V.Viloria and Flavia Nogueira (Department of Veterinary Medicine, Federal University of Viçosa, MG) for providing some tissue samples. E.F.Flores (352386/96-7) and R.Weiblen (520011/95) are recipients of scholarships from the Brazilian Research Council (CNPq). This work was supported by a MCT/CNPq/Finep and CAPES grant (PRONEX em Virologia Veterinária, 215/96).

\section{REFERENCES}

Baker J.1986. Bovine respiratory syncytial virus: immunopathogenesis, clinical signs,diagnosis and prevention. Infect. Dis. Food. Anim. Practice 8:62-68.

Bryson D.G., Ferran J.B. \& Ball H.J. 1979. Observations on outbreaks of respiratory disease in calves associated with parainfluenza type 3 virus and respiratory syncytial virus infection. Vet. Rec. 104:45-49.

Bryson D.G., McNulty M.S., Logan E.F., Cush P.F. 1983. Respiratory syncytial virus pneumonia in young calves: clinical and pathological findings. Am. J. Vet. Res. 44:1648-1655.

Campalans J.B. \& Arns C.W. 1995. Isolation of bovine respiratory syncytial virus in Brazil. Anais 5 a Virológica 95. Ribeirão Preto, SP. B-34.

Campalans J.B. \& Arns C.W. 1997. Serological evidence of bovine respiratory syncytial virus in Brazil. Virus Rev. Res. 2:50-55.

Driemeier D., Gomes M.J.P., Moojen V., Arns, C.W., Vogg G., Kessler L. \& Costa U.M. 1997. Manifestação clínico-patológica de infecção natural pelo vírus respiratório sincicial bovino (BRSV) em bovinos de criação extensiva no Rio Grande do Sul, Brasil. Pesq. Vet. Bras. 17:77-81.

Elvander M. 1996. Severe respiratory disease in dairy cows caused by infection with bovine respiratory syncytial virus. Vet. Rec. 138:101-105.

Gonçalves I.P.D., Simanke A.T., Jost H.C., Hötzel I., Dal Soglio A. \& Moojen V. 1993. Detection of bovine respiratory syncytial virus in calves of Rio Grande do Sul, Brazil. Ciência Rural, Santa Maria, 23:389-390.

Holzhauer C. \& Van Nieustadt A.P. 1976. De etiologische rol van het bovine respiratory syncytial virus bij pinkengriep. Tijdschr. Diergeneeskd. 101:1023-1031.

McNulty M.S., Bryson D.G. \& Allan G.M. 1983. Experimental respiratory syncytial virus pneumonia in young calves: microbiological and immunofluorescent findings. Am. J. Vet Res. 44:1656-1659.

Mohanti S.B., Ingling A.L. \& Lillie M.G. 1975. Experimentally induced respiratory syncytial viral infection in calves. Am. J. Vet. Res. 36:417-419.

Thomas L.H. \& Stott E.J. 1981. Diagnosis of respiratory syncytial virus infection in the bovine respiratory tract by immunofluorescence. Vet. Rec. 108:432435.

Van den Hingh T.S.G.A.M. 1982. Clinical and pathological observations on spontaneous bovine respiratory syncytial virus infections in calves. Res. Vet. Sci. 33:152-158.

Wellemans G.1977. Laboratory diagnosis methods for bovine respiratory syncytial virus. Vet. Sci. Commun. 1:179-189. 